time the recovery-rate seems to have been very satisfactory. In 1893 , owing to advancing years, Dr. Patton felt the need of assistance, and made proposals to the writer, then starting practice in Dublin, that he should become his assistant, with a view to succeeding him. The first part of this arrangement came into operation in the autumn of 1894 , while at the beginning of April, 1899 , just over ten years ago, the writer became proprietor and resident medical superintendent on the retirement of Dr. Patton.

During the past ten years the institution has been renovated, remodelled, and reorganised in every detail from end to end. To touch on only a few of the principal structural improvements, the entire drainage and sanitary system of the establishment have been relaid on modern lines, the kitchen and laundry refitted, and such changes in the internal arrangements carried out as most conduce to the comfort of the patients and to convenience in working, while additional accom. modation has been provided by the new addition already referred to. Out of doors the old airing-courts at Maryville have been cleared away and the space turned into an open garden; and, what has proved, perhaps, the most useful improvement of all, a walk about three-quarters of a mile long has been constructed round the whole estate, and forms a real boon to the patients. Especial attention has been paid to the social side of the work of the institution. A dance is held weekly, except during the summer months; and in addition a larger entertainment - concert, lantern-lecture, theatricals, garden-party or such-like-is given about once a month, while all the ordinary games are provided, such as hockey and golf in winter, and croquet, tennis and badminton in the summer months. With all this, however, every effort has been made to keep the medical side of treatment the really important one, and the various methods introduced into practice from time to time have been tried in appropriate cases. Thyroid treatment has yielded good results in our hands; supra-renal treatment, which was introduced here, has been found useful in certain cases; and the atropin treatment of inebriety has proved sufficiently successful to induce us to continue its employment. Apart from drugs, rest and diet treatment and the hydropathic method of the wet-pack have all been of service : while the latest introductions, vis., the open-air method, found so successful in America, and more recently in Scotland, and the administration of so-called Bulgarian milk, with a view to reducing the manufacture of toxins in the intestinal canal, are yielding encouraging results, though their introduction is too recent for positive assertions. Lastly, the staff has been increased so as to include at least two assistants (one unqualified), and an assistant matron in addition to the matron; while the nurses. and attendants are carefully trained for the Nursing Diploma of the Medico-Psychological Association, which has been obtained by many of the former.

An attempt was made to ascertain the number of cases admitted to the institution since its foundation. There are over 1,200 names on the books, but as voluntary boarders were received, of whom no record was kept until comparatively recently, the number of admissions is probably considerably larger, perhaps between 1,500 and 2,000 in all.

The meeting terminated with a vote of thanks to Dr. Dawson for his hospitality.

\title{
OBITUARY.
}

\section{Wit.liam Wotherspoon IRELAND, M.D.}

Dr. Ireland, who was so welcome and so familiar a figure at the meetings and congresses of the various medical societies, and so well known through his writings, died rather suddenly at his home in Musselburgh, on the 17th May, 1909, at the age of seventy-seven. He was the son of a publisher in Edinburgh, studied in the University there and in Paris, and entered the East India Company's service as assistant surgeon with the Bengal Horse Artillery shortly before the Mutiny broke out. During the Mutiny, at the siege of Delhi, he attended the wounded Lieutenant (now Lord) Roberts. After seven months service, when doing his duty like a hero, he was shot in the head; the bullet entered and destroyed the eye and passed out behind the ear; at the same time a bullet entered his shoulder and lodged in his back, this was afterwards extracted by the surgeons. 
It was a year before he could leave his bed, three years before he could undertake the voyage home, and ten years before he could enter on further professional work. During that tedious convalescence he lived in Madeira and various places on the Continent of Europe. He had many reminiscences and pleasant recollections of Savoy, and formed many lasting friendships. From the beginning Dr. Ireland showed a capacity for literature, general and professional. He wrote the History of the Siege of Delhi in 1861 , and ever since then he had been writing or translating almost continuously. During his convalescence he wrote two books, Studies of a Wandering Observer and Randolph Methyl, a tale of Indian life. Few men in our profession knew its literature so well. He turned his attention to mental disease after he was strong enough for work, and was appointed Medical Superintendent of the Larbert Institution for Imbecile Children, a post which he held for ten years, until he opened a private home for the defective at Polton, where he remained until his retirement to Musselburgh in consequence of Mrs. Ireland's death. His name is best known in connection with the two lines he especially took up. The one was idiocy and imbecility, and the other was the application of medico-psychology and studies in heredity, to the elucidation of the lives of certain men who have made a name in history, but who showed marked mental peculiarities, good and bad, and many of whom had a morbid mental inheritance. His Idiocy and Imbecility (1877), changed in title in its second edition to Mental Affections of Children (1900), has been our standard work in English on that subject since it came out. It is a book that was carefully and honestly written; it covers the whole ground he treats of, and its appreciation is shown by the fact that it has passed through two editions, the second greatly enlarged. The two books, in which his hereditary studies were applied to the problems of history, were the Blot on the Brain and Through the Ivory Gate. In those works, which are of great general interest, he treats of the Claudian-Julian family, Nero, Messalina, Caligula, and others as illustrating the effect of unchecked power on the characters of men. He also wrote an account of the Royal Family of Spain, which has great psychological and psychiatric interests. Royal families form the best field for studies in human heredity, because their members are necessarily well known. He also analysed the characters and work of Francis Xavier, Joan of Arc, Louis II of Bavaria; Guiteau the assassin of President Garfield; Riel, the half-breed Canadian; Theodore of Abyssinia, Luther, Ivan the Terrible, Paul of Russia, and one or two Eastern Sultans. His memoir of Swedenborg is ample and appreciative. Ireland seemed to revel in the borderland between sanity and insanity, and undoubtedly stimulated inquiry into the part which heredity and brain constitution has played in history, so much neglected by historians. He also published studies of Torquato Tasso Auguste Comte, and Friedrich Nietzsche, from the literary and psychological point of view, and wrote a biography of Sir H. Vane the younge-. Showing the range of his acquirements and tastes, he wrote on the "Effects of the Resinous Vapours of the Coniferæ on the Climate of Madeira," and on the "Arithmetical Faculty in Cerebral Disease." His translations and reviews for this and other journals were very numerous, for he had practical knowledge of French, German, Italian, Spanish, Norse and Hindustani. All he wrote was interesting and instructive. He did not cultivate brilliancy of style, but rather that of a solid and clear exposition. He was elected an honorary member of medical societies in Russia and Italy.

On the occasion of the jubilee of his graduation he was made the recipient of an illuminated address and presentation by a large number of his professional brethren, with whom he was always a favourite. He had an individuality in his appearance, laugh, walk, and character. He was never carried.away by new theories at once, and indeed, even as to facts that professed to be new he always took the position that they would have to be confirmed before they took their place in medical science. Showing that he could write to the point, one of his books was excluded from circulation in Russia because he had painted too true a picture of Ivan the Terrible in the Blot on the Brain. Many of his professional brethren, if they wanted a reference in regard to mental deficiency or mental disease, instinctively went to Ireland for it. It was said in the Address presented to him on the 4th March, 1905, the year of his jubilee as M.D. of Edinburgh, by the then President of the College of Physicians, Edinburgh,- - Above all those merits, your personal character, combining modesty and genial humour, earnestness and truthfulness, have 
won our respect and affection. We desire most cordially to express to you our wishes for a long and happy life, and still further usefulness. We believe that you will always enjoy the happiness of the man who 'keeps himself simple, good, sincere, grave, unaffected, a friend of justice, considerate, and strenuous in duty.'" In reply, Dr. Ireland said, amongst other things,- " He was not one of those who were in doubt as to life being worth living; he would gladly live his life over again, and he had found that his worst experiences had always taught him something." This from a man of seventy-two, whose first career had been blasted, who was blind in one eye, had just enough money to live on, and had many domestic sorrows in life, shows a spirit which we all might envy. It was the utterance of a lineal descendant of John Knox, through Mrs. Welsh, the daughter of the Reformer. His striking and kindly individuality will be much missed in Edinburgh medical circles, and at the meetings of the Medico-Psychological Association, and his constant devotion to the interests of this Journal renders Dr. Ireland's death a serious loss to all of us.

\section{BibliogRAPHY.}

History of the Siege of Delhi, by an Officer who served there. 8vo. Edinburgh : A. and C. Black, 1861 .

"On Pine Exhalations, and the Topography of Kusouli." Edinburgh Medical Fournal, 1862.

"On Japanese History." West minster Review.

Randolph Methyl, a Story of Anglo-Indian Life. London: Ward and Lock, 1863.

IVhat Food to Eat. 1865

Studies of a Wandering Observer. London: Chapman and Hall, 1867.

The Climate of Madeira. Edinburgh Medical Yournal, 1860.

The Mental Affections of Children. London: J. and A. Churchill, 1900. (A second edition of Idiocy and Imbecility, 1877.)

The Blot upon the Brain. Edinburgh: Bell and Bradfute, 1885. A second edition 1893 .

Through the Ivory Gate-Studies in Psychology and History. 8vo. Pp. 311. Edinburgh : Bell and Bradfute, 1889.

Golden Bullets, a Story of the days of Akber and Elisabeth. Edinburgh: Bell and Bradfute, $189 \mathrm{r}$.

On the Arithmetical Faculty in Idiocy and Insanity. 1891.

The Musical Faculty in Cerebral Disease. 1894

On the Means of Preventing and Evading Insanity. Alienist and Neurologist, 1894.

Life of Sir Henrv Vane the Younger, with a History of the Events of his Time. London: Evelyn Frost, 1905.

Reference may be made to the Index of this Journal for numerous articlese. $g$. "Flechsig on Localisation of Mental Processes," "Friedrich Nietzsche,"

"Comte," "Tasso," etc.

Henry Stilwel., M.D.

We regret to have to record the death of one of the senior members of this Association, Dr. Henry Stilwell, who for very many years was very regular in his attendance at its meetings. Very many of the elder members were on terms of warm friendship with him, inspired by his genial kindly disposition. His death took place at Eastbourne on A pril 12 th, at the age of seventy-three years. He was a son of the late Mr. James Stilwell, F.R.C.S., of Uxbridge. Educated at Rugby, he entered the medical profession by apprenticeship to his father. He became later a student at St. Bartholomew's on October Ist, 1853, and proceeded to Edinburgh to attend the lectures and complete his studies. He was admitted a member of the Royal College of Surgeons of England and a Licentiate of the Society of Apothecaries in 1857, taking the degree of Doctor of Medicine at the University of Edinburgh in the same year, at the early age of twenty-one years. After a voyage to Australia he was called upon to assist his father in general practice for two years in his native town, but relinquished it to join his cousin in 
the management of the asylum in that district. At Moorcroft, Hillingdon, he spent the greater portion of his life, having acted as medical superintendent of that institution for forty-five years. He retired in 1906 to live at Eastbourne, where he died after a short illness.

Dr. Stilwell was a man of sterling qualities and a good specimen of the English country gentleman-a man of wide culture, and with varied interests in life. In the "seventies" and "eighties" he was a well-known figure in the hunting field. In later years he had taken to golf as a recreation. Until recently he was a regular attendant at the St. Bartholomew's Hospital decennial dinners and at the dinners of the Edinburgh University Club, and was known to a wide circle of medical friends. Of a somewhat reserved disposition, he did not often enter into discussions at the ordinary medical societies, but he was an old and valued member of the Medico-Psychological Association, which he joined in 1862 . He was also a frequent attendant at the Metropolitan meetings of the British Medical Associa tion. For years he was the local secretary of the Epsom College Benevolent Fund, in which he took a great interest. In his own special department his opinion was sound and practical. Those who have been closely associated with him learnt much from him, and found that under the cloak of his somewhat austere manner was concealed one of the kindest hearts. He had also a fund of humour about him and was able to tell a good story.

Feeling the responsibility of his position in the care of the insane he entered into the lives of his patients, and by his example induced others to do their utmost to promote their recovery. He was much liked by his patients and respected by all who knew him. Dr. Stilwell leaves a widow, a son, and three daughters to mourn their loss. The funeral took place at Hillingdon on April 16 th in the presence of his son and sons-in-law, and many others.

\section{THE CONOLLY NORMAN MEMORIAL.}

At a meeting of the subscribers to the Conolly Norman memorial, held on June 8th in the Royal College of Physicians, Dublin, the report of the committee as to the arrangements made in reference to the memorial was before them, and the following resolutions were approved: (1) That the memorial shall consist of a mural tablet and bust of the late Dr. Conolly Norman, in bronze and marble, to be erected in St. Patrick's Cathedral, subject to the approval of the Dean; and a portrait in oils, to be placed in the hall of the Royal College of Physicians of Ireland.

\section{NOTICES BY THE REGISTRAR.}

The following is a list of the successful candidates at the Nursing Examination held in May, 1909 :

Chester County (Upton) Asylum.-Florence Lucy Robinson, John McGethrick. Cumberland and Westmorland Asylum.-Jeannie H. Hampson, David William Elloway, John R. Marrs, Margaret Barton, Agnes Hardy.

Glamorgan County Asylum.-Charles Henry Arthur, James Jones, James Fortune.

Herts County Asylum.-Herbert H. Hewitt, Susanna Twainley.

Kent County (Maidstone) Asylum.-Edith Wyld, James Bridges, Louis Downs William Jeffery.

Kent County (Chartham) Asylum.-Nellie Smith, Ada H. Franklin.

Lancaster County Asylum.-Ruth Tyldsley, Walter S. Webb, James Baird, Jessie Revely, Louisa Butham, Margaret Richmond, Annie Warhurst, Lizzie Russel, Mary Egan, Jessie Tears, Annie Pearson, Dora M. Bailey, Susannah Webster.

Lancashire County (Whittingham) Asylum.-Thomas Tennant, William Murray, Charles Mahon, John William Fussey, John Dixon, George H. Douglas, Annie Pickthall, Eleanor Inglesfield, Miriam Warth, Thomas C. Hall, Charles L. Milton, Samuel Rowland. 